\title{
Evaluation of DSSAT-CERES model for irrigation scheduling of wheat crop in Varanasi region of Uttar Pradesh
}

\author{
CHANDRABHAN PATEL ${ }^{* 1}$, A.K. NEMA ${ }^{1}$, R.S. SINGH ${ }^{2}$, M.K. YADAV ${ }^{2}$ S.K. SINGH ${ }^{3}$ and SHIV \\ MANGAL SINGH²
}

${ }^{1}$ Department of Farm Engineering, Institute of Agricultural Sciences, BHU, Varanasi-221005

${ }^{2}$ Department of Geophysics, Institute of Science, BHU, Varanasi-221005

${ }^{3}$ Department of Soil Science and Agril. Chemistry, Inst. of Agril. Sci., BHU, Varanasi-221005

*Corresponding author E-mail: chandrab263@gmail.com

\begin{abstract}
The DSSAT-CERES-Wheat model (V-4.6) was calibrated and validated using field experiment data (2008-2014) collected on phenology, yield and yield attributes of four cultivars ( HUW 234, Kundan, HUW 510 and PBW 373) of wheat for Varanasi. The simulated yields were very close to observed grain yield as evident from $\mathrm{R}^{2}$ of 0.96 with $\mathrm{nRMSE}(4.92 \%)$ and $\mathrm{D}$-index (0.99). The simulated phenological events and yield attributes of wheat cultivars were also in good agreement. Therefore, the model was used for evaluation of irrigation scheduling in wheat crop. The results revealed that the model performance was good under three, four and five irrigation scheduling while poor performance was observed under two and one irrigation treatments.
\end{abstract}

Key words: Evaluation, DSSAT-CERES model, wheat, irrigation scheduling,Varanasi.

Wheat (Triticumaestivum L.) is the second most important food grain crop of India and is associated with the food security of the country.In Uttar Pradesh, it ranks first in respect of crop coverage area (9.67 million ha) and production (33.66 million tons) however the average productivity is less (3.41 tons ha. ${ }^{-1}$ ) (Anonymous, 2013-14). The eastern Uttar Pradesh share about 34\% acreage and $32 \%$ production of wheat in Uttar Pradesh (Singh et al., 2014). The wheat production is highly variable due to climatic variability. There is a great challenge for sustainable wheat production in the country.

Crop simulation models are valuable tools for evaluating potential effects of environmental, biological and management factors on crop growth and developments. These tools are handy and provide practical means for scheduling irrigations. In the past, these model has been successfully utilized in irrigation planning for crop (Behera and Panda, 2009), optimization of irrigation water use (Fortes et al., 2005; Bulatewicz et al., 2009), comparison of various scenarios and strategies (Rinaldi, 2004; Rinaldi et al., 2007), spatial water requirement of rice crop (Kandiyal et al., 2015) and many more. For eastern Uttar Pradesh regions studies have been concentrated on the effect of climate change on phenology, grain yield (Yadav et al., 2015) and yield gap, potential yield (Aggrawal et al., 2000), yield forecasting
(Nain et al., 2004) etc. The present study is aimed at the evaluation of DSSAT-CERES-Wheat model for irrigation scheduling on wheat crop.

\section{MATTERIALS AND METHODS}

A field experiment was conducted on four cultivars wheat (HUW 234, Kundan, HUW-510 and PBW 373) under FASAL (Forecasting of Agricultural output using Space, Agrometeorology and Land based observation) project at the Agricultural Research Farm of Institute of Agricultural Sciences, BHU, Varanasi during 2011-14. The data were also collected from the field experiments conducted at Agricultural Research Farm, BHU, Varanasi during 2008-12 for calibration and validation of CERES-Wheat model (Table 1).

The genetic coefficients required in the CERES wheat model for four cultivars of wheat were estimated by repeated iterations in the model calculations until a close match between simulated and observed phenology, growth and yield were obtained. The genetic coefficient determined for all cultivars of wheat crop used for simulation of irrigation scheduling are presented in Table 2.

The validation of model was done using data, which was not used for calibration. The capability of the model to predict was tested by judging the performance of crops in 
Table 1: Description of experiment of different wheat cultivars

\begin{tabular}{lllll}
\hline Experimental details & HUW 234 & KUNDAN & HUW 510 & PBW 373 \\
\hline Years of experiment & $2008^{*}, 2009^{*}$, & $2011^{*}, 2012^{*}$, & $2008^{*}, 2009^{*}$, & $2010^{*}, 2011^{*}$, \\
& $2010^{*}, 2011^{*}$, & $2013^{* *}, 2014^{* *}$ & $2010^{*}, 2011^{*}$, & $2012^{*}, 2013^{* *}$, \\
& $2012^{*}, 2013^{* *}$, & & $2012^{*}, 2013^{* *}$, & $2014^{* *}$ \\
& $2014^{* *}$ & & $2014^{* *}$ & \\
\hline Emergence & $3-6$ & $5-7$ & $4-6$ & $5-7$ \\
Anthesis days & $74-83$ & $78-82$ & $70-77$ & $76-82$ \\
Maturity days & $102-118$ & $107-115$ & $102-112$ & $107-115$ \\
Grain yield $\left(\mathrm{kg} \mathrm{ha}^{-1}\right)$ & $2597-3938$ & $2542-4977$ & $2681-4769$ & $2694-4977$ \\
Straw yield $\left(\mathrm{kg} \mathrm{ha}^{-1}\right)$ & $3629-7200$ & $3467-7189$ & $3807-7216$ & $3666-7189$ \\
Harvest Index $(\%)$ & $33-45$ & $32-43$ & $35-44$ & $34-43$ \\
\hline
\end{tabular}

${ }^{*}$ Data used for calibration

${ }^{* *}$ Data used for validation

Table 2: Genetic coefficients of the wheat cultivars.

\begin{tabular}{|c|c|c|c|c|c|}
\hline Code & Parameters & HUW 234 & KUNDAN & HUW 510 & PBW 373 \\
\hline $\mathrm{P} 1 \mathrm{~V}$ & $\begin{array}{l}\text { Days at optimum vernalizing temperature required to } \\
\text { complete vernalization. }\end{array}$ & 20 & 20 & 20 & 20 \\
\hline P1D & $\begin{array}{l}\text { Percentage reduction in development rate in a } \\
\text { photoperiod } 10 \text { hour shorter than the threshold } \\
\text { relative to that at the threshold. }\end{array}$ & 80 & 70 & 75 & 65 \\
\hline P5 & Grain filling (excluding lag) phase duration $\left({ }^{\circ} \mathrm{C} . \mathrm{d}\right)$ & 750 & 695 & 700 & 690 \\
\hline G1 & Kernel number per unit canopy weight at anthesis $(\# / g)$ & 25 & 24 & 26 & 22 \\
\hline G2 & Standard kernel size under optimum conditions ( $\mathrm{mg}$ ) & 40 & 36 & 38 & 38 \\
\hline G3 & $\begin{array}{l}\text { Standard, non-stressed dry weight (total, including } \\
\text { grain) of a single tiller at maturity }(\mathrm{g})\end{array}$ & 1.1 & 1 & 1.3 & 1.2 \\
\hline PHINT & Interval between successive leaf tip appearances $\left({ }^{\circ} \mathrm{C} . \mathrm{d}\right)$ & 95 & 90 & 90 & 95 \\
\hline
\end{tabular}

Table 3: Irrigation scheduling details of wheat crop.

\begin{tabular}{lccc}
\hline Irrigation scheduling & $\begin{array}{c}\text { Amount of } \\
\text { irrigation }(\mathrm{mm})\end{array}$ & $\begin{array}{c}\text { Number of } \\
\text { irrigation }\end{array}$ & $\begin{array}{c}\text { Total }(\mathrm{mm}) \\
\text { water applied }\end{array}$ \\
\hline $\mathrm{I}_{1}$ : Crown root initiation (21 DAS) & 50 & 1 & 50 \\
$\mathrm{I}_{2}:$ CRI + Booting (75 DAS) & 50 & 2 & 100 \\
$\mathrm{I}_{3}:$ CRI + Tillering (45 DAS) + Booting & 50 & 3 & 150 \\
$\mathrm{I}_{4}:$ CRI + Tillering + Booting + Milking (100 DAS) & 50 & 4 & 200 \\
$\mathrm{I}_{5}:$ CRI + Tillering + Jointing (65 DAS) & 50 & 5 & 250 \\
Flowering (85 DAS) + Milking (100 DAS) & & & \\
\hline
\end{tabular}

terms of grain yield and phenology. The model performance was tested using statistical parameters viz. standard deviation, linear regression parameters, coefficient of determination, root mean square error (RMSE), normalized root mean square error (nRMSE) and D-index etc.

Also, a field experiment was conducted on irrigation scheduling (irrigation applied at $\mathrm{I}_{1 ;}$ Crown root initiation, $\mathrm{I}_{2}$ CRI + Booting, $\mathrm{I}_{3 ;}$ CRI + Tillering + Booting, $\mathrm{I}_{4 ;} \mathrm{CRI}+$ Tillering + Booting + Milking and $\mathrm{I}_{5 ;} \mathrm{CRI}+$ Tillering + Jointing + Flowering + Milking) with four wheat cultivars $\left(\mathrm{V}_{1}\right.$; HUW 234, $\mathrm{V}_{2}$; Kundan $\mathrm{V}_{3}$; HUW510 and $\mathrm{V}_{4} ;$ PBW 373) during 2013-14 and 2014-15 (Table 3). Calibrated and 

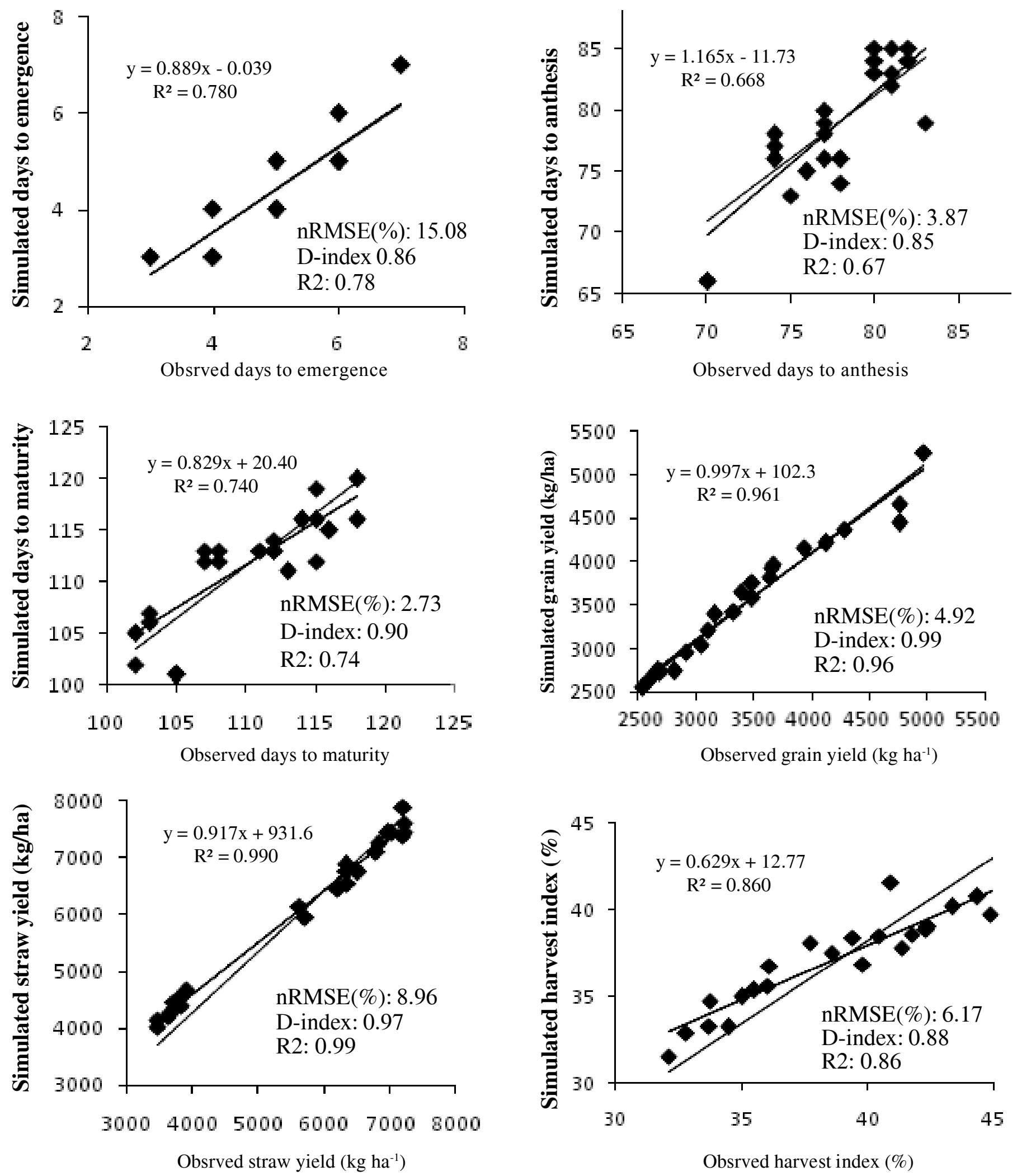

Fig 1: Comparison of simulated and observed phenology and yieldfor all cultivars of wheat.

validated model was used for simulation of effect of irrigation scheduling on grain and straw yield of wheat crop.

\section{RESULTS AND DISCUSSION}

The observed and simulated phenological events like 
Table 4:Evaluation of DSSAT-CERES model for different irrigation scheduling and different cultivars of wheat.

\begin{tabular}{|c|c|c|c|c|c|c|c|c|c|c|c|c|}
\hline \multirow[t]{2}{*}{ Treatments } & \multicolumn{6}{|c|}{ Grain yield $\left(\mathrm{kg} \mathrm{ha}^{-1}\right)$} & \multicolumn{6}{|c|}{ Straw yield $\left(\mathrm{kg} \mathrm{ha}^{-1}\right)$} \\
\hline & SIM & OBS & RMSE & $\begin{array}{c}\text { nRMSE } \\
(\%)\end{array}$ & D-index & $\overline{\mathrm{R}^{2}}$ & SIM & OBS & RMSE & $\begin{array}{c}\text { nRMSE } \\
\left(\%{ }^{1}\right)\end{array}$ & D-index & $\mathrm{R}^{2}$ \\
\hline \multicolumn{13}{|l|}{ Irrigation } \\
\hline $\mathrm{I}_{1}$ & 2118 & 2363 & 263 & 11.11 & 0.63 & 0.84 & 3348 & 3184 & 200 & 6.34 & 0.59 & 0.84 \\
\hline $\mathrm{I}_{2}$ & 2436 & 2568 & 171 & 6.66 & 0.73 & 0.66 & 3673 & 3384 & 301 & 8.88 & 0.40 & 0.52 \\
\hline $\mathrm{I}_{3}$ & 2655 & 2643 & 60 & 2.28 & 0.98 & 0.94 & 3848 & 3450 & 349 & 9.92 & 0.52 & 0.73 \\
\hline $\mathrm{I}_{4}$ & 2714 & 2723 & 62 & 2.27 & 0.98 & 0.91 & 4154 & 3662 & 506 & 13.82 & 0.34 & 0.66 \\
\hline $\mathrm{I}_{5}$ & 2830 & 2790 & 57 & 2.02 & 0.98 & 0.94 & 4335 & 3733 & 607 & 16.25 & 0.36 & 0.90 \\
\hline $\mathrm{SEm} \pm$ & - & 66.9 & - & - & - & $\longrightarrow$ & - & 89.4 & - & - & $\longrightarrow$ & - \\
\hline $\mathrm{CD}(\mathrm{p}=0.05)$ & - & 148.3 & - & $\longrightarrow$ & - & $\longrightarrow$ & - & 198.2 & $\longrightarrow$ & - & $\longrightarrow$ & $\longrightarrow$ \\
\hline \multicolumn{13}{|l|}{ Cultivars } \\
\hline $\mathrm{V}_{1}$ & 2868 & 2606 & 174 & 6.11 & 0.89 & 0.88 & 3912 & 3507 & 439 & 12.53 & 0.64 & 0.95 \\
\hline $\mathrm{V}_{2}$ & 2520 & 2413 & 85 & 3.40 & 0.91 & 0.86 & 3713 & 3372 & 394 & 11.70 & 0.47 & 0.81 \\
\hline $\mathrm{V}_{3}$ & 2664 & 2691 & 151 & 5.66 & 0.92 & 0.96 & 4033 & 3599 & 470 & 13.05 & 0.67 & 0.97 \\
\hline $\mathrm{V}_{4}$ & 2484 & 2577 & 73 & 3.06 & 0.97 & 0.91 & 3828 & 3523 & 348 & 9.86 & 0.73 & 0.96 \\
\hline $\mathrm{SEm} \pm$ & 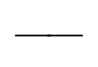 & 42.0 & - & - & - & $\longrightarrow$ & $\square$ & 55.6 & 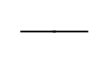 & $\longrightarrow$ & $\longrightarrow$ & - \\
\hline $\mathrm{CD}(\mathrm{p}=0.05)$ & 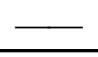 & 82.5 & 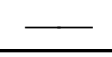 & $\square$ & $\square$ & $\square$ & $\longrightarrow$ & 109.2 & 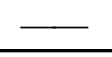 & - & 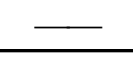 & 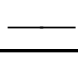 \\
\hline
\end{tabular}

days to emergence, anthesis and maturity, and yields are presented in Fig 1. The model performance parameters viz. nRMSE, D-index and $\mathrm{R}^{2}$ show the correctness of the model and values are also given on the figures. The results show that model is able to simulate days to emergence, anthesis and maturity reasonably well for most of treatments. In general, there was a good agreement between the observed and simulated values. Fig 1 also shows good agreement between simulated and observed values of grain yield, straw yield and harvest index for all cultivars for all sowing dates. The result show that model is able to simulate grain yield, straw yield and harvest index for all cultivars reasonably well for most of treatments.

\section{Effect of irrigation scheduling on grain and straw yield}

Model evaluation was performed for simulation of grain yield treated with irrigation schedule at different stages of wheat (Table 4). Simulated grain yield increased with increasing irrigation levels. The lowest grain yield $\left(2118 \mathrm{~kg} \mathrm{ha}^{-1}\right)$ was recoded with one irrigation and maximum grain yield $\left(2830 \mathrm{~kg} \mathrm{ha}^{-1}\right)$ with five irrigations. Model performance parameters viz. RMSE (263 to $171 \mathrm{~kg} \mathrm{ha}^{-1}$ ), nRMSE (11.11 to $6.66 \%)$, D-index $(0.63$ to 0.73$)$ and $\mathrm{R}^{2}(0.84$ to 0.66$)$ were less in one and two irrigation scheduling, in comparison to three, four and five irrigation treatments,
RMSE ( 60 to $57 \mathrm{~kg} \mathrm{ha}^{-1}$ ), nRMSE (2.28 to $2.02 \%$ ), D-index $(0.98)$ and $\mathrm{R}^{2}(0.91$ to 0.94$)$. Model performance parameters were better under three, four and five irrigation treatments (optimum condition of irrigation water) in comparison to treatments having two and one irrigation (stress condition of irrigation water). Performance of all four cultivars were good as nRMSE less than 7 and D-index more than 0.89 for grain yield.

The lowest straw yield ( $\left.3348 \mathrm{~kg} \mathrm{ha}^{-1}\right)$ was recoded with one irrigation and maximum straw yield $\left(4335 \mathrm{~kg} \mathrm{ha}^{-1}\right)$ with five irrigations (Table 4). Model evaluation indices viz. RMSE varied from 200 to $607 \mathrm{~kg} \mathrm{ha}^{-1}$, nRMSE from 6.36 to 6.25 per cent, D-Index from 0.34 to 0.59 and $\mathrm{R}^{2}$ varied from 0.52 to 0.90 under different irrigation treatments. Cultivar; PBW 373 has lowest error and better performance in comparison other cultivars i.e. HUW 234, Kundan and HUW 510 regarding grain and straw yield (Table 4). The result show that increasing of irrigation number in wheat crop increased the RMSE and $n$ RMSE between simulated and observed straw yield and decreased the $\mathrm{D}$-index value. Therefore, it is required to improve the CERES-wheat model for irrigation scheduling in wheat crop in case of straw yield. However, performance for grain yield were good under three to five (optimum condition) irrigation treatments, while poor 
performance was recorded with one and two irrigation treatments.

\section{CONCLUSIONS}

DSSAT-CERES-Wheat model (V 4.6) calibrated and validated for wheat cultivars in Varanasi region suggested that model performance was good under optimum condition of irrigation water while poor performance was observed under stress condition of irrigation water. Therefore, it is required to improve the model for good performance in stress condition of wheat crop.

\section{AKNOWELDEMENT}

Authors are thankful to Ministry of Earth Science and India Meteorological Department, Govt. of India, New Delhi for providing the financial and technical assistance to carry out the present experiment in the form of fellowship and "Field Experiment" budget under FASAL project.

\section{REFERENCES}

Anonymous(2013-14). Directorate of Economics and Statistics, Department of Agriculture and Cooperation.

Aggrawal,P.K., Talukdar, K.K. and Mall, R.K.(2000). Potential yield of rice-wheat system in the Indo-Gangetic plains of India. Rice-Wheat Consortium Paper Series 10. New Delhi, India: "Rice-Wheat Consortium for the IndoGangetic Plains.”pp 16.

Behera, S. K.and Panda, R. K. (2009). Integrated management of irrigation water and fertilizers for wheat crop using field experiments and simulation modeling. Agr. Water Manage., 96(11): 1532-1540.

Bulatewicz, T., Jin, W., Staggenborg, S., Lauwo, S., Miller, M.,
Das, S. and Welch, S. M. (2009). Calibration of a crop model to irrigated water use using a geneticalgorithm. Hydro. Earth Syst. Sci., 13(8): 1467-1483.

Fortes, P. S., Platonov,A. E. and Pereira, L. S. (2005). GISAREGA GIS based irrigation schedulingsimulation model to support improved water use. Agr. Water Manage., 77(1):159-179.

Kadiyala, M.D.M., Jones, J.W., Mylavarapu, R.S., LI, Y.C., Reddy, M.D. and Umadevi, M.(2015). Study of spatial water requirements of rice under various crop establishment methods using GIS and crop models. $J$. Agrometeorol., 17:1-10.

Nain,A.S., Dhawal, V.K. and Singh, T.P.(2004). Use ofCERESWheat model for wheat yield forecast in central IndoGangetic Plains of India. The J.Agricul. Sci., 142:5970 .

Rinaldi, M. (2004). Water availability at sowing and nitrogen management of durum wheat: a seasonal analysis with the CERES-Wheat model. Field Crops Res., 89(1):2737.

Rinaldi, M., Ventrella, D., \&Gagliano, C. (2007). Comparison of nitrogen and irrigation strategies in tomato using CROPGRO model. A case study from Southern Italy. Agricul. Water Manage., 87(1): 91-105.

Singh, R.S., Patel, C., Yadav, M.K. and Singh, M.K. (2014). Yield forecasting of rice and wheat crops for eastern Uttar Pradesh. J. Agrometeorol., 16(2):199-202.

Yadav, M.K., Singh, R.S., Singh, K.K., Mall, R.K., Patel, C.B., Yadav, S.K. and Singh, M.K. (2015). Assessment of climate change impact on productivity of different cereal crops in Varanasi, India. J. Agrometeorol., 17(2):179184. 